timbers, Australia has not been behind other parts of the Empire. In 1933 the Division of Forest Products of the Council for Scientific and Industrial Research published as a pamphlet Part 1 of "A Guide to the Seasoning of Australian Timbers", in which it was pointed out that timbers of different species frequently differ so widely in physical properties that it is impossible to prescribe a general set of conditions for air-drying or kiln-drying for all timbers, or even for all sizes of one timber. Part 2 of this Guide has been recently issued (Div. of For. Products, Pamphlet No. 68, Technical Paper, No. 22. Melbourne, 1937) written by W. L. Greenhill and A. J. Thomas. The work of determining suitable kiln schedules for various species and sizes of timber is being carried out in laboratory kilns, supplemented by information operated by the Queensland forest service. Based on the results of the work carried out since the publication of Part 1, seasoning notes and suggested schedules for twenty-two additional species are given in the present pamphlet.

\section{Tuberculosis in the Far East}

THE problem of tuberculosis was one of the subjects dealt with at the Conference of Far Eastern Countries on Rural Hygiene last August (League of Nations. Health Organisation. Report of the Intergovernmental Conference of Far-Eastern Countries on Rural Hygiene. Held at Bandoeng (Java), August, 1937. London: George Allen and Unwin, Ltd. 2s. 6d.). Tuberculosis is recognized as being one of the scourges in Eastern countries. Unfortunately, there is an almost complete absence of accurate data concerning the extent and severity of the disease in rural areas. The importance of carrying out preliminary surveys and sample tuberculin tests in the country is advo. cated. Financial limitations make it important that an anti-tuberculosis campaign should be simple and adapted to local conditions, and the gradual establishment of a network of rural dispensaries would appear advisable. The establishment of sanatoria, in the Western sense, would not seem to be applicable, but simpler institutions are suggested. A scheme for mass research on tuberculin sensitiveness was drafted.

\section{Chinese Medicine and the Pangolin}

The pangolin or scaly ant-eater (Manis pentadactyla dalmanni) is the most primitive of Chinese mammals, and although it is fully protected by law in the colony and island of Hong-Kong, the demand for its carcass makes more extensive protection in South China necessary (Hong Kong Naturalist, July 1937, 79). The animal itself is eaten, but a greater danger arises from the belief that the scales have medicinal value. Fresh scales are never used, but dried scales are roasted, ashed, cooked in oil, butter, vinegar, boy's urine, or roasted with earth or oystershells, to cure a variety of ills. Amongst these are excessive nervousness and hysterical crying in children, women possessed by devils and ogres, malarial fever and deafness. So much are pangolin scales in request for these purposes that yearly the scales from some 4,000 or 5,000 individuals were imported from Java, with a value of 3,700 guilders.
But recent regulations in Java, which prohibit capturing and killing of pangolins and the export of scales, will turn the attention of the Chinese medicine men more forcibly towards the native product.

\section{James Eights : a Pioneer Antarctic Naturalist}

Dr. W. T. Calman has done worthy service to the memory of an American naturalist of the early nineteenth century in his presidential address to the Linnean Society (Proc. Linn. Soc., 149, 171; 1937). The accuracy of the descriptions and drawings made by James Eights, his discovery of a ten-legged pycnogon (Decolopoda), in which no one believed until the rediscovery of the species by the Scottish National Antarctic Expedition almost seventy years later, his discovery of a new seal and a new dolphin, neither of which he named, his description of the breeding of the king penguin, and of the South Shetland Islands, all mark him as a naturalist of keen perception. It is unfortunate that the appearance of his descriptions in journals not readily accessible should have obscured and delayed the recognition of his merit, and more sad to learn that in his own country he dropped out of the current and lived for a quarter of a century, until his death in 1882, in loneliness, obscurity and poverty.

\section{Spectrograms of Nova Herculis 1934}

THE editors of the Astrophysical Journal in 1935 collected data as to the spectrograms of Nova Herculis 1934 available at different observatories, partly with a view to the ultimate production of an atlas showing the changes day by day in the spectrum of the star during the first few months after the initial outburst. On the appointment of a Nova Subcommission in the Commission of Stellar Spectra of the International Astronomical Union, this material was handed to Prof. F. J. M. Stratton as chairman of that Sub-commission. Further data as to the observational material available were secured, and now the spectrum of Nova Herculis for nearly every day is available from one source or another from the head of the Balmer series to $H \alpha$. The Solar Physics Committee at Cambridge has approved the production by the staff of the Solar Physics Observatory of an atlas showing daily changes over that range of spectrum. It is hoped to print the whole atlas on 16 stiff cards-one quarter of the spectrum on each card and one card for each month. The cost will depend on the number of subscribers to the atlas, and subscribers may be asked to pay as much as 25 shillings. If sufficient support is forthcoming, it is hoped to start work on the atlas early in 1938.

\section{Rabies Prevention in India}

DetaILs of the preventive treatment of rabies at the Pasteur Institute of India, Kasauli, are given in the thirty-fifth annual report for the year 1935 by the director, Dr. R. O. A. Smith. The total number of patients attending the Institute and its centres was 21,898, an increase of 657 patients as compared with the previous year, of whom 16,627 received the 
complete course of treatment. There were 86 deaths among these, a percentage death-rate of 0.52 , which compares with $0 \cdot 49$ for the previous year. In addition, 1260 courses of vaccine for the prophylactic treat. ment of animals were issued during the year. The vaccine employed is a carbolized 5 per cent emulsion of sheep's brain prepared from sheep infected with the Paris fixed virus.

\section{Twenty-Five Years of Research in Dairying}

TWENTY-FIVE years ago the National Institute for Research in Dairying, University of Reading, was founded, and to celebrate the event an "Anniversary Review", compiled by the staff of the Institute, has been issued. This booklet presents a short history of the origin and development of the Institute, with a brief account of its present relationship with the farm, the dairying industry generally and the public. A summary is also given of the many and varied investigations carried out at the Institute, or in collaboration with other research centres, mainly between 1923 and the commencement of the present year.

\section{Announcements}

Prof. Richard KuhN will deliver the sixth Pedler Lecture of the Chemical Society at the London School of Hygiene and Tropical Medicine on January 27 at 5.30 p.m. The subject of the lecture will be "Synthesis of Polyenes".

THE medical faculty of the University of Zurich has elected Dr. William Cortedge of Rochester, U.S.A., an honorary doctor in recognition of his work on applied physics in medicine especially in roentgenology.

THE Rockefeller Foundation of New York has decided to award Profs. A. Kluyve of Delft and L. S. Ornstein of Utrecht financial support for five years for their radiobiological investigations, which have already been supported by the Foundation for three years.

THE Women's Medical Association of New York City offers the Mary Putnam Jacobi Fellowship (1000 dollars for one year) which is available for post-graduate work in the medical sciences. The fellowship is open to any woman graduate of an approved medical school. Further information can be obtained from Dr. Phoebe Du Bois, 150 East 73rd Street, New York.

THE Ophthalmological Society of the United Kingdom has instituted a Treacher Collins Prize of $£ 100$, which will be awarded every three years for the best essay submitted on a subject selected by the Council. It will be open to medical practitioners of any nationality, but the essay must be in English. The first subject selected is cerebro-spinal disease and its relation to the optic nerve. Essays should be submitted to the honorary secretary, 5 Racquet Court, Fleet Street, E.C.4, before December 31, 1938.

Dr. Hermann Win'sz, professor of obstetrics and gynæcology at Erlangen, has been awarded the Carlos
Heiser Medal by the International Commission of Radiologists and Roentgenologists.

AN Italian society of metaphysics has recently been founded in Rome with a presidential council consisting of Prof. Ferdinando Cazzamalli, Dr. Luigi R. Sanguineti, Prof. G. Schepia and Dr. Emilio Servado. Further information can be obtained from the secretary, Dr. L. R. Sanguineti, Via Serbelloni 2, Milan.

THE twenty-seventh Dutch Congress of Natural Science and Medicine will be held at Nymwegen on April 11-13, 1939, under the presidency of Prof. G. Holst of Eindhoven. Further information can be obtained from the general secretary, Dr. D. Coelingh, Bussum, Holland.

A LAW for the reorganization of the University of Brazil and construction of the University City at Rio de Janeiro recently passed the House of Deputies. The Federal Government is now in charge of the construction of the University City, which will include the faculties of philosophy, education, fine arts, engineering, mining and metallurgy, chemistry and pharmacy, law, politics and economy, agriculture, veterinary medicine and music. There will also be a hospital.

"Рнотоmicrography with the Vickers Projection Microscope" is the title of a booklet published by Messrs. Cooke, Troughton and Simms, Ltd., Buckingham Works, York, the present makers of the instru. ment, which was originally designed and manufactured at the Erith Works of Messrs. Vickers-Armstrong, Ltd. The apparatus is fully deseribed, together with the electrical equipment and instructions for assembly. The manner of using and maintenance are described, and chapters are devoted to the theory of the microscope and preparation of specimens. The booklet contains much information on the subject of photomicrography and the use of the microscope in steel works practice, apart from the Vickers instrument, and is fully illustrated.

Assistance in the selection of suitable scientific books for public libraries is always welcomed. We are glad to see, therefore, that Prof. B. W. Holman, who is a member of the Brentford Borough Council, has contributed to the January issue of the Fordwick - a quarterly list of books added to the Brentford and Chiswick Public Libraries-a short article on recent books on social and other non-technical aspects of science.

"T. LL. H." informs us that in his review of Sir Frederick Maurice's "Life of Lord Haldane", the date of the appointment of the Royal Commission (NATURE, Dec. 11, p. 989) should have been 1909, not 1907 .

Erratum. In the last line but one of the letter by Dr. A. S. Parkes entitled "Terminology of Sex Hormones" in NATURE of January 1, p. 36, for "thryotrophic" read "thyrotrophic". 